\title{
Causes of wildland fires, associated socio- economic impacts and challenges with policing, in Chakari resettlement area, Kadoma, Zimbabwe
}

\author{
Luckson Chinamatira', Spikelele Mtetwa ${ }^{1}$ and George Nyamadzawo ${ }^{2^{*}}$
}

\begin{abstract}
Zimbabwe is among the most fire prone countries in Africa south of the Sahara. Annually over 1 million hectares of land are destroyed by wildland fires during the fire season which runs from July to November. Wildland fires are caused by several agents, cost huge socio and economic loses and are difficult to police. The objective of this study was to evaluate the causes of wildland fires, associated socio-economic impacts and challenges associated with policing wildland fires in Chakari resettlement area. Although the area studied was small compared to the whole country, the results showed typical challenges that are faced in many resettlement areas in Zimbabwe. The study used multiple sources of information including review of published literature, reports from regulatory agencies, questionnaires, interviews and field observations. The results from the study showed that $86 \%$ of the respondents suggested that wildland fires are caused by human negligence and deliberate arson, $14 \%$ suggested that wildland fires are caused by natural factors such as lightning and spontaneous ignition, while $6 \%$ suggested that events such as vehicle and locomotive accidents and electron clouding of power lines cause wildland fires. The major human causes of wildland fires were cited as hunting and bee harvesting (84\%), burning of crop residues and land preparation ( $80 \%)$, burning homestead surroundings to improve visibility (79 \%) and deliberate arson was cited by $61 \%$ of the respondents. Using the contingency valuation method, the estimated average income loss from wildland fires was US\$1 $408 \mathrm{ha}^{-1}$ year $^{-1}$. The major challenges faced in policing wildland fires included poor community participation in fire related activities (69\%), absence of deterrent fines (64\%), complexity of the crimes (51\%), inadequate training (45\%) and lack of resources (40\%). Fire management should move away from fire fighting to prevention and sustainable practices such as early burning. In addition there is need for extensive training of communities on fire management and managing ignition sources. Policing of wildland fires can be improved through availing more resources towards policing, improved training, establishing partnerships with local population and leadership, and empowering traditional leadership to police wildland fires.
\end{abstract}

Keywords: Wildland fires, Fire season, Policing, Tropical areas, Fire management

\footnotetext{
*Correspondence: gnyama@yahoo.com

${ }^{2}$ Department of Environmental Science, Bindura University of Science

Education, Box 1020, Bindura, Zimbabwe

Full list of author information is available at the end of the article
} 


\section{Introduction}

Wildland fire refers to uncontrolled fires burning in an area with combustible vegetation (Moore et al. 2002). The origins of wildland fires dates back even to the era before human creation when its origin was simply natural. Since then fire has also rendered service to mankind for so long, without impacting negatively on how people relate to their environment. The tropical savannas of Africa are among the most fire prone ecosystems in the world and fires generally occur during the dry season or early wet season, at intervals of 1-5 years (Huntley 1982; Trollope 1982; 1984). However, the problems of wildland fires are not peculiar to Zimbabwe alone, but to many countries in Africa e.g. Zambia (Frost 1992), Tanzania (Kilahama 2011) and other tropical countries such Indonesia (Saharjo 1995, 2009), South America (Pinto and Alvarado 2011; Nepstad et al. 1999), Australia (The Guardian 2015). There are several causes of wildland fires. Causes of fires include people who ignite fires to clearing land for cultivation, smoking out beehives, making charcoal, cooking or trying to keep warm, arson and as a way of settling disputes. Phiri et al. (2011) argued that recent increase in fire incidences has been attributed to newly resettled smallholder farmers. This is mainly because resettled farmers use fires for land preparation (Goldammer 1993). The same sentiments were also supported by Environmental Management Authority (EMA) (2013) which recorded the highest numbers of fires in the resettlement areas. In Indonesia, Saharjo (1995) reported that burning is practiced by farmers because the ash that is released is rich in organic carbon and minerals such as phosphorus, magnesium, potassium and sodium. As a result the some areas are burnt on an annual basis to improve soil fertility.

Frost (1992) added that in the Southern African region some fires are started deliberately between the early winter and early summer by livestock owners seeking to promote a green flush for their animals, by rodent hunters clearing vegetation to catch their prey more easily, by people creating firebreaks around their homesteads or seeking to improve visibility, or by individuals playing with fire.

In Zimbabwe cases of arson, were fires are used to settle disputes have been reported in large-scale forested areas where employees are disgruntled over non-payment of salaries or low salaries (Nyamadzawo et al. 2013). Nepstad et al. (1999) also identified forest fires as being used as a weapon in land tenure or land use disputes. Wildland fires can also be a result unextinguished roadside fires used by travelers and long distance truck drivers for cooking and warming especially in winter time. In addition, lit cigarettes thrown out from moving vehicles have been reported to cause roadside fires. These observations were supported by a report by EMA (2011) which showed that $60 \%$ of all wildland fires occurred within $500 \mathrm{~m}$ from major highways. In addition vehicle, locomotives and electricity power lines accidents have been reported to cause wildland fires. There has been reports of trucks that caught fires along the major highways or vehicles that burn following accidents, with the end result being wildland fires. In addition to these anthropogenic causes of wildland fires, there are also natural causes such as spontaneous fires and lightning. Although, most dry-season wildland fires are ignited by man, lightning becomes probably the most common natural cause of wildland fires at the beginning of rain season (Komarek 1972; West 1972).

The negative impacts of forest fires, have received worldwide media coverage (Moore et al. 2002). Examples include the Tillamook burn in Oregon in 1933 that destroyed over 310000 acres (Ortolano 1997). In Zimbabwe in 2012 alone, more than 1 million hectares of land was destroyed by wildland fires, including property worth more than USD\$200 000. In 2010, five deaths occurred due to wildland fires, while in 2011 twenty five deaths were attributed to wildland fires (The Herald 2011). According to the Timber Producers Federation, in 2011 more than 10 \% of Zimbabwe's pine forests of economic value were destroyed by wildland fires alone.

Fire outbreaks have resulted in increased loss of agricultural produce, reduced food availability for both humans and animals, reduced growth rate of vegetation, and loss of equipment (WWF 2001; Nyamadzawo et al. 2013). Acute impacts such as trauma, loss of shelter and property, e.g. the destruction of a home or damage to personal goods, can be a source of grief, stress and people whose lives and property are threatened by wildland fires may experience a feeling of helplessness (Machilis 2002). According to Nyamadzawo et al. (2013), in most African cultures, poor homeless people are often stigmatized, and the loss of livelihoods sources may result complete disintegration of the family unit. The result is that the resource-poor smallholder farmers are ushered deeper into a poverty cycle.

Wildland fires affects different people differently, hence costs and benefits vary among different segments of the population and also site (Jordan 1985). The feminist theory found that wildland fires negatively affects livelihood of female in society. For instance, Sturgeon (1997) asserts that without modern energy sources, cooking meals and heating lead many women to rely on traditional energy sources like firewood, coal, fertilizer and agricultural waste. Wildland fires causes physical energy and time loss while fetching firewood from distant places. Furthermore, Fernandes and Geeta (1987) suggest that in parts of the Himalayas and the African Sahara, women and children spend 100 to 300 days a year on gathering fuel wood which is scarcer following wildland fires. Jackson and Fisher (2007) also reported that in rural areas where most of the people cannot afford to buy corrugated roofing 
sheets, women and young girls waste their hours and energy looking for thatch grass so as to meet the shelter needs of their families after wildland fires have consumed all grass that is used for thatching.

However, the impacts of fires are not always negative as fires can also improve the growth of more palatable grass which provides grazing for animals in the dry season, removal of old and normally less palatable dry plant material, the control and reduction of bush encroachment, the stimulation of germination of some useful species of grass, and trees and also the limitation of animal parasites such as ticks, (WWF 2001; Nkomo and Sassi 2009). In addition, fires may stimulate the germination of seeds after fires (Sabiiti and Wein 1987). However, the use of fires should be regulated to minimise damage to fauna and flora. Philips (1930)) commenting on dangers of wildland fires and asserts that "fire in vegetation is a bad master, a good servant and a national disaster".

The impacts of wildland fires needs not to go without saying that the situation warrant state intervention to maintain social justice through policing for sustainable development. In this context policing shall include the efforts by all legal environmental management agents which include Environmental and Forestry Officers, the Police and local chiefs and headman to govern the use of fires to conserve resources. Law enforcement can minimize illegal burning which produce negative impact (Saharjo 2009). In biblical times the Israelites had a commandment that; "if fire breaks out...., so that stacks of corn or the standing corn, or the field, be consumed therewith: he that kindled the fire shall make restitution" (Exodus $22 \mathrm{v}$ 6), (The Bible 2013). In Zimbabwe before colonialism, punishment for violating the cultural environmental laws was overseen by the chief, in a tete-à-tete with the great Shona spirit "Mhondoro" such that anyone caught setting fire risked expulsion from the area or losing his wealth by decree.

However, of late, in Zimbabwe most of the traditional practices of punishing violators of environmental laws have been abandoned and this has seen a sharp increase in cases of wildland fires. According to the national crime statistics there were 20,974, 1115,1074 and 920 cases of arson that were received in 2010, 2011, 2012, 2013 and 2014 respectively (Zimstats Quarterly Digest of Statistics 2015) and only few people have been arrested and none has been asked to pay restitution. The failure by policing agents to arrest arsonists has increased fear and anxiety among farmers in most smallholder farming areas, as they fear having their crops destroyed by fires. Compared to burglary or murder, environmental crime is markedly complex (Alvesalo 2002). Evidence is extremely difficult to gather and authorities are usually called in after an offence has long been committed and the suspect would have vanished. Furthermore, our local police authorities (who account for the vast majority of policing in our country) are simply not trained to detect fire related crime. Even if the offender is identified, prosecuting such a crime is complex, time consuming and expensive. For example, in 2013, a total of 129 dockets or court records were opened for fire related offences and of these only 67 went through the courts resulting in only three people being convicted and given custodial sentences ranging between 3 to 12 months (EMA 2013). To exacerbate the challenge of poor policing, the political and economic crisis that occurred between 2000 and 2009 in Zimbabwe deepened the incapacity of state institutions to enforce environmental laws due to many challenges in policing. To date most of these policing agents have not fully recovered to do effective policing on fire related crimes. Thus, the objective of the study was to assess causes wildland fires, associated socio-economic impacts and challenges associated with policing in Chakari resettlement area of Zimbabwe. Chakari is typical of many resettlement areas in Zimbabwe.

\section{Materials and methods Study site}

The study was conducted in Chakari resettlement area which is a mining village in Kadoma district of Mashonaland West province, Zimbabwe. Chakari is located about $33 \mathrm{~km}$ west of Chegutu and $38 \mathrm{~km}$ north of Kadoma. Chakari is located in Sanyati Rural district which covers an area of $57,676.7 \mathrm{~km}^{2}$. The population density is 26 inhabitants per $\mathrm{km}^{2}$ according to the 2012 census with a projected change of $2.06 \%$ annually for 2002 to 2012. Chakari is located $18^{\circ} 4^{\prime} 0^{\prime \prime}$ South, $29^{\circ} 51^{\prime}$ $0 "$ East (Fig. 1), in an area in natural region (NR) IIb with annual rainfall between $700-800 \mathrm{~mm}$ according to Zimbabwe's classification of farming areas. Chakari is typical many resettlement areas in Zimbabwe and the results from this study typical show the challenges that are faced in these resettlement areas. The soils are red clay in nature and support the growth of very tall grasses which provides fuel for wildland fires (Mudekwe 2007).

\section{Data collection}

Stratified random sampling in which the population was grouped into strata according to villagers and policing agents was first applied. During the survey, both qualitative and quantitative techniques were used. The qualitative tools used included field observations, use of archived materials and interviews. These tools facilitated wildland fire risk analysis process by estimating the potential threat to people, property and the environment on which they depend upon.

A systematic sampling procedure to select respondents from each village was used. Systematic sampling was preferred for villagers because it can be used even where no list is available but households are arranged in an easy geometric pattern (Wegner 2007). At the beginning 


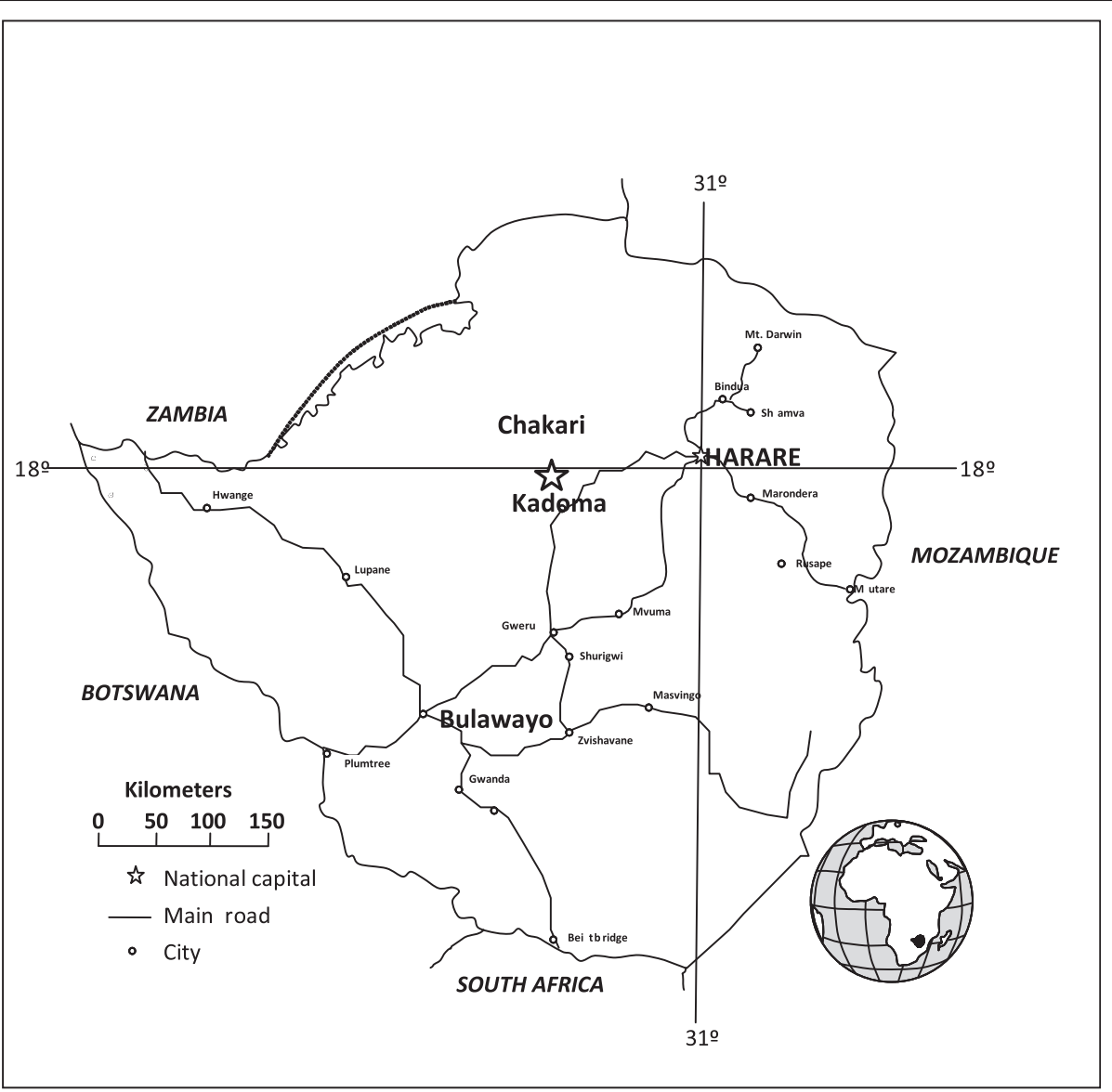

Fig. 1 Map of Zimbabwe showing the location of Chakari

of the interviews process, the reasons for the study were explained to manage expectation (Mabeza and Mawere 2012). In addition, the researchers also explained respondent's rights not to respond to certain questions.

This research was carried out using a sample population of 58 households from a total population of about 280 households which was $20 \%$ of the sampling intensity (Pinto and Alvarado 2011). A sampling intensity of $20 \%$ per each stratum was used and this ensured that one individual is sampled per every 5 households across all strata. The sampling interval was calculated using the equation [1] (Sampling Methods and Sample Size Calculation for the SMART Methodology 2012) Available at: https://www. humanitarianresponse.info/system/files/documents/files/ Sampling_Paper_June_2012.pdf.

Sampling Interval $=\frac{\text { Total number of basic sampling units }(S B U) \text { in the population }}{\text { Number of }}$

Policing agents interviewed included the Zimbabwe Republic Police (ZRP), Environmental Management Authority (EMA), forestry commission officers and local chiefs. In addition other key informants such as agricultural extension officers, village heads, and the headman were interviewed, in addition to informal interviews, and direct field observations. All questionnaires and interviews were done at the villagers' or the local leaderships' homesteads or at the offices of the policing agents (ZRP officers, EMA and forestry commission officials) and key informants (Extension officers) to facilitate a relaxed conversation. In addition, other sources of information were explored, and these included ZRP crime records and EMA fire reports, archival evidence from files and other records kept by police, the Forestry Commission, published and unpublished literature.

\section{Data analysis}

Responses from the farmers were coded and categories formed around the codes. The categories and data were analysed using the Statistical Package for Social Sciences (SPSS version 16). Where the data was of a qualitative nature that is, revealing perceptions, feelings and emotions generalizations were drawn from themes.

\section{Results}

The average response rate for the questionnaires that were distributed was $90 \%$ and this gave a good 
confidence to conclude that the research findings were representative of the views of the population of Chakari. Fifty four percent of the respondents were male, while $46 \%$ were female and $77 \%$ of the population had stayed in Chakari for 6-15 years. The community was relatively new, and most of the households moved into the area at the onset of the agrarian reform program in 1999. Only $13 \%$ of the respondents had stayed for more than 16 years.

All respondents in this study were aged between 16 and 75 years of age. The age range $16-75$ years was preferable as most of them participated in issues related to wildland fires. According to section 39(1) of Zimbabwe's Criminal Procedure and Evidence Act Chapter 9, section 7, every male inhabitant between the ages of 16 and 60 is, required to assist any peace officer when requested to do so. The Forest Act of Zimbabwe, section 67(2)(b)(ii) also makes reference to this age group. The modal age group category was 26-35 years which comprised $27 \%$ of the participants, while $23 \%$ was from $16-25$ years age group. The $36-75$ years age group made up $50 \%$ of the respondents.

Majority of respondents (87\%) agreed that wildland fires are a major problem in Chakari area, while only $13 \%$ of respondents did not take wildland fire as a problem. The majority of the respondents ( $86 \%$ ) agreed that most wildland fires are caused by human negligence and deliberate arson, while $8 \%$ perceived natural factors (such as lightning) as the cause of most wildland fires and $6 \%$ suggested that accidents such as mechanical faults of locomotives, vehicle accidents and electron clouding from power lines caused wildland fires.

Eighty four percent of the respondents agreed that the main causes of wildland fires are hunting and bee smoking during honey harvesting. The burning of crop residues and land preparation for farming was cited by $80 \%$ of the respondents as the second most common cause of wildland fires. Burning homestead surroundings to improve visibility was cited by $79 \%$ of the respondents to be causing wildland fires, while $61 \%$ of the respondents suggested that wildland fires are caused by deliberate arson.

In addition, the other causes of wildland fires that were highlighted included fire from roadside servitudes $(60 \%)$, fires from cigarettes stubs (51\%), fires from rubbish pits and settling of land were cited by $39 \%$ of respondents. Population increase was also cited as a major cause of wildland fires. The increase in human population in Chakari has been fuelled by continuous land allocation, particularly in areas where farmers are given virgin land. Land clearing to prepare agricultural fields causes wildland fires when fires used for land clearing get out of hand.

\section{Impacts of wildland fires in Chakari}

Sixty percent of the respondents indicated that fires if well scheduled and managed are beneficial to the ecosystem, they stimulate fresh growth, eliminate poisonous plant species, destroys parasites like ticks, red ball worm, caterpillar and other cotton pest larvae. Other benefits included destroying garden pest and livestock predators as well as clearing land for next farming season. However most of the respondents maintained that despite these benefits, there is no proper time when all grass should be removed as it lead to loss of grazing land and burning dry grass causes cattle to scramble for little green growth.

However, the impacts of wildland fires are not always positive. About $16.1 \%$ of the respondents have suffered and experienced losses as a result of wildland fires. Eight percent of the respondents from Montana village indicated that wildland fires destroyed their gardens and vegetables in 2012 resulting in estimated total loss of USD\$300. One farmer indicated that his granary was gutted by fire from the neighbouring farm and a total of five tonnes of maize was lost in the process. Another farmer lost thirteen fowl valued at $\$ 78$ when the fowl run was gutted by wildland fires. Several respondents indicated that their huts were destroyed by infernos and property such as clothes were destroyed as a result of wildland fires. The other impacts of wildland fires affecting Chakari include the death of livestock from wildland fires, loss of firewood, destruction of fruits and herbs (Table 1).

The farmers in Chakari also obtain natural resources such as thatch grass, firewood and building materials from the forests which are often at the mercy of wildland fires. Thirty two percent of the respondents indentified burning of thatch grass and trees in general as the major impact of wildland fires. Wildland fires were also blamed for livestock mortality as they may fail to escape the infernos and this was very common especially with young animals (Table 1). The other negative impacts of wildland fires that were highlighted included the destruction of crops in fields, burning of fire wood, injury to forest and destruction of wild fruits and traditional herbs and medicine, and burning of pastures for livestock.

In Chakari the forest provided a source of livelihood for a significant number of the population. About $60.3 \%$

Table 1 Some of highlighted socio-economic impact of veld fires

\begin{tabular}{llr}
\hline Impacts & Frequency & Percent \\
\hline Livestock death and straying & 12 & 19.3 \\
Destruction of field crops & 4 & 6.5 \\
Depletion of fire wood & 08 & 12.9 \\
Destruction of thatch grass and trees & 20 & 32.2 \\
Loss of fruits and herbs & 2 & 3.2 \\
Loss of grazing & 16 & 25.8 \\
Total & 62 & 100.0 \\
\hline
\end{tabular}


percent of the respondents indicated that they relied on sales of thatch grass, firewood or fruits from the forest. The study site was a major source of fire wood and thatching grass which was supplied to the nearby mining town of Chakari and other surrounding towns. Therefore the forest was a major source of income to rural poor who were not formally employed. The study indicated that $50 \%$ respondents relied on income from sales of natural resources and on average households earned USD \$57 per month, with a range between USD\$10 and USD\$150, from selling forest related products.

The community of Chakari benefited a lot from selling forest related products. This means that apart from the individual peculiar loss due to wildland fires, the community as a whole also suffered collectively by loosing forest related products. The contingency valuation technique was employed to assess how much the community valued their resources. The result was that on average a farmer is willing to contribute $\$ 3.7 \pm \$ 1.3$ per household towards wildland fire management. This was in response to the question on how much the respondents would want each household in Chakari to contribute towards wildland fire management, purchase of firefighting equipment and for the maintenance of fire guards. The proposed amounts that respondents were willing to contribute are shown in Table 2.

Using the contingency valuation technique, the total value of estimated loss was $\$ 1039 \pm \$ 370$ per hectare, calculated from $\$ 3.7 \pm 1.3 \times 280$. However, as people normally propose to pay less than the value they get, this prediction sought to avoid over exaggerating phenomena by taking the average estimated value lost especially when compared to the minimum amount that an individual gets from sales of natural resources stated above.

\section{Challenges in policing wildland fires}

Policing wildland fires is affected greatly by several factors. The majority of respondents (69\%) cited poor community participation in issues of fires management as a major challenge in policing wildland fires. Corruption was highlighted $67 \%$ of the respondents as another major challenge on effective policing in Chakari. The other perceived challenge was that of absence of deterrent punishment, which was cited by $64 \%$ of respondents. In addition, $51 \%$ of respondents indicated that complexity in crimes is a challenge in policing wildland fires.

Table 2 The proposed household contributions towards environmental upkeep in Chakari

\begin{tabular}{lllllll}
\hline $\begin{array}{l}\text { Amount of proposed household } \\
\text { contributions (\$) }\end{array}$ & 1 & 2 & 3 & 4 & 5 & 6 \\
Percent (\%) of respondents & 6 & 10 & 29 & 30 & 14 & 11 \\
\hline
\end{tabular}

Inadequate training was cited by $45 \%$ of the respondents, and lack of resources as highlighted by $40 \%$ of the respondents as a cause of poor policing of wildland fires. In the national police force, there are specialised departments, such as criminal investigation department (CID) and traffic, but there is no specialised department dealing with the environment or wildland fires. There is also a general lack of transport to visit wildland fire sites and to carryout investigations. This has resulted in poor policing of wildland fires.

Table 3 shows the numbers of wildland fires escalated in 2012. Out of the 52 reported wildland fire cases, only one case was finalised at court between 2011 and 2013 . A few dockets/court files were compiled showing that the policing agents prefer the regulatory approach of assessing fines to evade the hectic court process which waste much of their time. This is an indication that court process is not succeeding as only one wildland fire case was finalised since 2011. This suggests that policing wildland fires is a challenge Chakari.

Another important factor affecting the effectiveness of policing was legislation which was cited by $31 \%$ of respondents. The analysis of the legal framework in Zimbabwe reveals that statutory instrument 7 of EMA Act 20:27 at section 17(2) of 2007 says "In case of a fire outbreak any person within the vicinity of the fire other than the user or the owner of that land shall carefully and properly extinguish the fire". It was established such section is difficult to enforce as one cannot rely on a passerby to put out fire as he or she is not equipped and has no experience in fire fighting.

Some of the respondents highlighted that the stripping of powers of local custodians of law such as chiefs as causes of wildland fires. Instead of arresting people causing wildland fires, the chiefs are actually supposed to go and report the perpetrators to the police, forestry commission and EMA officials. Community leadership also acknowledges that their powers as custodians of environmental laws have been taken over by police and EMA so they are reluctant to act since they are powerless.

\section{Discussion}

The majority of respondents in Chakari noted that wildland fires as a major problem and similar cases have been reported in many other new smallholder and resettlement farming areas of Zimbabwe which were established following the Fast Track Land Reform Program (FTLRP) (Phiri et al. 2011; EMA 2011). Though a small number of farmers did not indicate that wildland fires were a problem, differences in opinions and perceptions are expected. In Bolivia, Pinto and Alvarado (2011) observed a difference in perception of the problem of wildland fires were attributed to difference in land use practices. Cattle owners, thatch grass sellers and those 
Table 3 Reported cases of veld fires in Chakari from 2011-2013

\begin{tabular}{llllll}
\hline Year & Veld fire cases reported & Tickets /citations issued & Dockets opened & Dockets to court & Finalised cases at court \\
\hline 2011 & 13 & 20 & 3 & 1 & NIL \\
2012 & 21 & 32 & 6 & 4 & 1 \\
2013 & 18 & 34 & 1 & 1 & NIL \\
\hline
\end{tabular}

Source: EMA records 2013 submitted to Z.R.P Chakari

practising bee keeping take wildland fire as a challenge because it affects their business most, while farmers who use fires for land preparation and as a source of nutrient (Goldammer 1993; Garren 1943; Jordan 1985; Saharjo 1995) will not view wildland fires as a challenge.

Most farmers in Chakari suggested that most wildland fires were caused by human errors, or negligence, while a small percent cited natural causes. Similar observations were also reported by Williams et al. (2011), who observed that only one event out of eight mega fires worldwide was attributed to electrical faults and none was due to lightning while seven were suspected to have been caused by human error. The results are also consistent with the sentiments by Huntley (1982) and Trollope (1982), who say that "in the savannas, lightning related fires generally occur during the dry season or early wet season, at intervals of 1-5 years". West (1972) added that most dry-season wildland fires are ignited by man, but lightning becomes important at the beginning of the rains. Most key informants also agreed that human negligence and arson were the major causes of wildland fires in Chakari and in many other resettlement areas in Zimbabwe. The respondents concurred that though lightning caused wildland fires, the fires did spread because of the wet conditions or rains.

Hunting and bee harvesting were also cited as the major causes of wildland fires. In tandem with the current study Pinto and Alvarado (2011) in Bolivia found that the main causes of wildland fires were the hunters, followed by the burning of grasslands and slash, vandalism and unextinguished cigarettes. In Tanzania, Kilahama (2011) also reported that other major causes of wildland fires included game hunting, where fires were deliberately set to drive wild animals to intended destiny or to attract them, and also to allow re-growth in burnt areas for an easy catch.

Land clearance and preparation for cropping was cited among the top causes of wildland fires. These findings reaffirm the assertion by Goldammer (1993) that most wildland fires in smallholder farming areas occur during land preparation for agricultural purposes. A similar position was also reported by Kilahama (2011); Phiri et al. (2011) and EMA (2011). A report by EMA (2011) also showed that $80 \%$ of the wildland fires occurred in A1 and A2 model resettlement farming areas where most of the new farmers used fires for land clearance.
Negligence was cited as the major cause of wildland fires in Chakari and the increase in the number of people settling the area has reportedly resulted in an increase in the number of fires. This is in agreement with the fire ignition model by Zumbrunnena et al. (2011) which suggested that as population increases, the cases of wildland fires also increases. In addition, arson was also cited as a major challenge. The local leaders reported that poverty contributed to arson as poor farmers without livestock sometimes deliberately set fire to fix livestock owners.

The observation that most wildland fires emanated from the roadsides was not peculiar to Chakari alone. Several studies (e.g. EMA 2011; Nyamadzawo et al. 2013) have reported that fire left at bus stops and fire from cigarettes stubs which are negligently thrown out from moving vehicles were major causes of wildland fires. A report by EMA (2011) showed that $60 \%$ of all fires occur within $500 \mathrm{~m}$ from major roads and this suggested that road sides are the sources. In most cases vegetation along roadsides is trimmed to improve visibility along the roads. This vegetation provides ready fuel when fires are left unextinguished at bus stops, by long distance truck driver or from lit cigarettes stubs that are thrown from moving vehicles.

Though most wildland fires have far large negative impacts, fires also have positive impacts on the ecosystem. The positive impacts of wildland fires include, breaking seed dormancy and improving grazing. The WWF (2001); Nkomo and Sassi (2009) reported that wildland fires improve the growth of green grass which provides grazing for animals in the dry season, the fires also help with the removal of old and normally less palatable dry plant material, the control and reduction of bush encroachment, the stimulation of germination of some useful species of grass, and trees and also the elimination of animal parasites such as ticks. Seeds may be stimulated to germinate after fires (Sabiiti and Wein 1987), and many woody plants in savannas produce multiple coppice shoots to replace those lost or damaged through fires (Shackleton and Scholes 2000).

The negative impacts of wildland fires are huge and include the loss of property, crops, forest products and grazing, to name a few. Nyamadzawo et al. (2013) reported that in Zimbabwe acute impacts such as trauma are common among victims who their crops are destroyed by fires. In addition, the loss of shelter, personal goods through wildland fires has often left families traumatized, often 
families sleep in the open with no food supplies and proper water and sanitation facilities and this may result in stress, and can be a source of grief (Nyamadzawo et al. 2013). The overall impact of wildland fires is increased insecurity among households.

The study also showed that there is a major loss of natural resources, such thatching, and firewood are lost as a result of wildland fires. These observations are in agreement with the eco-feminist theory, which argue that women, girls and children are the most affected by wildland fires as firewood becomes scarce causing rural girls to travel long distance in search of firewood and thatching grass for thatching their huts.

The study also revealed that communities are willing to pay for the protection of the wildland and properties from wildland fires. Wildland fires which are occurring on an annual basis in Chakari, have caused loss in the ecosystem services and goods that are obtained by the community. However, the estimated annual income loss averaged $\$ 1$ $039 \mathrm{ha} \mathrm{yr}^{-1}$, and was lower than the estimate by Costanza et al. (1997) \$2 $007 \mathrm{ha} \mathrm{yr}^{-1}$ for the ecosystem services for tropical biome $(1,900 \times 106$ ha globally).

\section{Policing Wildland Fires}

This study showed that policing of wildland fires is a major challenge in Chakari and this has been attributed to several reason among them lack of cooperation between members of the community and the policing officers. This is mainly because the community plays two roles; that is they are the perpetrators in most incidences of wildland fires outbreaks, whether intentionally or accidentally and at the same time they are the ones who are supposed to notify the policing agents, thus conflict of interest occurs when ones relative, neighbour, friend or child is the perpetrator. A study by Jackson (2007) on the effectiveness and limitations of policing wildland fires revealed that issues of conflict of interest were found to be crippling the criminal justice system. Societies have struggled to strike a balance between conserving biodiversity and protecting their communities and families from policing agents.

Corrupt policing practices were also cited as a challenge in policing wildland fires. Dube and Mafoko (2009) also echoed that it is partly because of corruption that the general public has grown to be reluctant to come forward to report on who or what caused a fire. Some respondents would argue the some officers would receive bribes so that they can set perpetrators of wildland fires free, as a result it does not make a difference whether the case is reported or not. Lack of appropriate punishment has been attributed to increasing wildland fires (Nyamadzawo et al. 2013). Leaf (2002) also shared the same sentiments when he said the current Roman-Dutch system is increasingly believed to be excessively lenient and consequently ineffective at controlling wildland fire crimes because it provides insufficient deterrence against offending.

The lack of adequate training and lack of resources was also cited as a challenge in policing wildland fires. The absence of a specialised national wildland fire department, makes policing a challenges as most of the officers are not trained to handle fire cases. There is also a general lack of transport to visit wildland fire sites and to carryout investigations. Police officers at time use public transport to carryout investigations. This can at times compromises their work, as they may the given transport by offenders. This has resulted in poor policing of wildland fires.

The complexity of fire crimes in courts has been a major challenge in policing wildland fires. Alvesalo (2002) in line with this says compared to a burglary or a murder, environmental crime is considered markedly complex. This is also evidenced in the regulatory framework where police and EMA can be notified after 7 days and suspects would have vanished. Prosecuting such a crime is complex, time consuming and expensive. For this reason Leaf (2002) and EMA (2013) asserts that regulatory agencies refer a very limited number of offenders to the courts for criminal charges. Similar findings were reported by Jackson and Fisher (2007) in Indonesia were no trial by courts took place following the severe fire outbreaks where 176 forest concessionaires, plantation companies and transmigration area developers were accused of using fire for land clearing activities. Though the authorities investigated 13 companies, only five where brought to court; however, no company was punished as their cases were dismissed due to the technical difficulties (Jackson and Fisher 2007).

The study also showed that local community leadership is concerned because their powers as custodians of environmental laws have been taken over by government policing agents (ZRP, forestry commission and EMA). A study conducted in Botswana by Dube (2013) on the challenges in policing fires indicated that the legal fraternal inhibit community participation in wildland fire management. A potential option is to integrate local leadership in wildland fire management, for example using CommunityBased Fire Management (CBFiM). Myers (2006) in support says that community inclusive fire management strategy has a potential to be sustainable because it will be cost effective in the long run.

\section{Other ways of improving policing of wildland fires}

i. Increasing enforcement of regulations The policing agents use the powers vested in them to prevent, detect and deter crime. For example, section 25 of the Criminal Procedure and Evidence Act: Chapter 9:07 states that peace officers are 
empowered to intervene whenever they have good reason to believe that an offence has been (or, is about to be) committed. Therefore, the Police, EMA and forestry officers can be effective form of formal surveillance. During routine patrols regulatory agents can check compliance with the fire prevention, and suppression laws. However, Wilson (1975) argued against the relevance of police patrols, he asserts that the financial cost of increasing the number of police patrols far outweighs the localised and short term effects of crime rates. Furthermore according to Wilson (1975) the value of police arrest is dependent on what the criminal justice system does with the offender because once the matter is handed over to the courts, the courts cannot be controlled by the policing agents.

ii. Policing and Community participation Engaging community in fire management has been proved to be worthwhile in both developed and developing countries and it has come to be known as Community-Based Fire Management (CBFiM) (Moore et al. 2002). Burrows et al. (1979) suggested that in reality for police to be effective, they need the support of the community, because for the police make any arrest, they will do so using information obtained from the public rather than catching the offender red-handed. Policing normally target to punish illegitimate use of fires, minimise errors and negligence as preventive measures (Laris and Wardell 2006). However, this has an effect of isolating the society by treating them as agents that causes wildland fires, than those that can prevent. Correct policing, should allowed community participation in veld fire management. For example, the community can enforce the construction of labour intensive fire guards better than the policing officers. Members of the community are also in a better position to identify culprits who caused wildland fires than officers based at stations kilometers away. This way, fire management becomes more inclined towards fire prevention and it also progressively becomes more of a community issue than a central Government issue (Magole 2009).

iii. Rapid response to wildland fires and fire fighting operations

Communities and the police should be prepared to fight fires all the time. Community warning mechanisms often come from the local people notifying the regulatory agents about wildland fire occurrence. Their response and policing preparedness rely on resource availability (Ganz and Moore 2002). However, in Zimbabwe, section 18 of the Environment Management Act, Chapter 20:27 requires that police and EMA should be notified of a fire outbreak within 7 days of occurrence of offence. The requirement has resulted in poor policing efforts, as there is no urgency in having the policing agents at the site of a fire crime and there is also a possibility that the suspect would have vanished after 7 days. In addition, evidence may be extremely difficult to gather in such situations. The delay in attending the scene of the crime and collecting evidence has made prosecuting such a crime very complex, time consuming and expensive and as a result only very limited number of offenders are taken to the courts for criminal charges (Leaf 2002). Because of the challenge that are currently faced in policing wildland fires, it is suggested that the current system be integrated with the use of modern technology such as satellite data for planning fire prevention, prescribed burning and suppression. This will reduce centralisation of fire management and improve efficiency (Ganz and Moore 2002). However, such technology is often unavailable to rural populace in third world nations. In addition wildland fire management and policing should be governed by the economical principles, protecting lives and assets, as effective and efficient fire management programme requires a balance between the benefits society receives from the use of fire and the costs, damages or undesirable impacts caused by unwanted fire (Van Lierop 2011).

\section{Conclusions}

This study showed several anthropogenic causes of wildland fires in Chakari. The study identified hunting and smoking out bees during harvesting of wild honey, land clearing by farmers, back burning to reduce the fuel load around homesteads, arson, carelessness such as throwing out lit cigarettes and increase in population density as the major causes of wildland fires. Though wildland fires were found to be beneficial in some instances, their negative impacts however outweighed the benefits when not properly managed. The negative impacts of wildland fires were found to loss of property, livestock, firewood, grazing and other economic goods and services with an estimated value of USD\$1 $0389 \mathrm{ha}^{-1} \mathrm{yr}^{-1}$. Effective policing can potentially reduce wildland fires. However, policing wildland fires is affected greatly by lack of public support, lack of resources, corruption, inadequate training, ambiguous laws, lack of deterrent measures, punishments or fines, complexity in crimes and the annexation of the powers of local leaders. In order to improve the impact of policing issues of legislation should grant and decentralise legal and policing powers to the traditional leadership so that they can preside of wildland fire cases as a way of enhancing public participation. The current environmental law in Zimbabwe, EMA Act, requires 
traditional leaders to compile reports and send them to the policing agents and this has caused challenges with policing wildland fires. There is also need to integrate fire fighting, the training of the police force and to form a wildland fire crimes department to deal specifically with the issues of wildland fires. The police force should also be equipped to fight fires and they need to be provided with basics such as vehicles to carry out their work. The idea of willingness to pay explored in this study can be a starting point to involve community as the fire fighters may be paid by community and the money raises can help create fire guards as early as possible before the fire season.

\section{Abbreviations}

CBFiM: Community-Based Fire Management; CID: Criminal investigation department; EMA: Environmental Management Authority; ZRP: Zimbabwe Republic Police; FTLRP: Fast Track Land Reform Program; WWF: World Wide Fund.

\section{Competing interests}

Mr L. Chimanatira is a member of the Zimbabwe Republic Police. He collected the data as part of his Research Project for a Honours Degree in Police and Security Studies.

\section{Authors' contributions}

LC, was responsible for the conception and design, or acquisition of data, analysis of the data and generating a draft manuscript. SM was responsible assisting with data interpretation, and revising the draft manuscript. GN was involved in drafting the manuscript and revising it for important intellectual content and gave final approval of the version to be published. All authors agree to be accountable for all aspects of the work in ensuring that questions related to the accuracy or integrity of the work are appropriately investigated and resolved. All authors read and approved the final manuscript.

\section{Authors' information}

LC Holds a BSc honours. In Police and Security Studies. He is an active member of the Zimbabwe National Police force.

SM holds a MA in Policy Studies, BA education, and a Diploma in Education. GN holds PhD in Agriculture, an MPhil in Soil Science and MSc in Agriculture, BSC (Honours) in Soil Science and a Diploma in Science Education. He is the current coordinator of the Natural Resources Management (NRM) programme in the Department of Environmental Science.

\section{Acknowledgents}

We are grateful for the permissions from EMA, ZRP and Forestry Commision to carryout this work. We are also grateful to the Montana, Twinlands and Rondo communities in Chakari for allowing us to carryout this work in their area.

\section{Author details}

${ }^{1}$ Department of Intelligence and Security Studies, Bindura University of Science Education, Box 1020, Bindura, Zimbabwe. ${ }^{2}$ Department of Environmental Science, Bindura University of Science Education, Box 1020, Bindura, Zimbabwe.

Received: 17 August 2015 Accepted: 27 January 2016

Published online: 05 February 2016

\section{References}

Alvesalo A (2002) Downsized by Law, Ideology, and Pragmatics- Policing White-Collar Crime. Anderson Publishing, Cincinnati

Burrows CJ, McQueen DR, Esler AE, Wardle P (1979) New Zealand heathlands. In: Specht RL (ed) Ecosystems of the world. 9A. Heathlands and related shrublands: descriptive studies. Elsevier Scientific Publishing Company, Amsterdam, pp 339-364

Costanza R, Darge R, Groot R, Farberk S, Grasso M, Hannon B et al (1997) The value of the world's ecosystem services and natural capital. Nature 387:253-260
Dube OP (2013) Challenges of wildland fire management in Botswana: Towards a community inclusive fire management approach. Weather and Climate Extremes 1:26-41

Dube OP, Mafoko JG (2009) Botswana case study. SAFNet, Africa Environment Outlook Case Studies: Impacts of Fires on the Environment, SARDC, Thomas Theis Nielsen, Nairobi, p 7-17

Environmental Management Authority (EMA) (2013) Fire assessment report. Barnaby Printing and Publishing, Harare, pp 4-5

Environmental Management Authority, EMA (2011) Fire assessment report 2011. Environmental Management Authority, Benaby Printing and Publishing, Harare

Fernandes W, Geeta M (1987) Tribal Women and Forest Economy: deforestation, exploitation and social change. India Social Institute, New Dehli

Frost PGH (1992) A policy framework for fire management in the Western Province of Zambia. LDP, Mongu

Ganz D, Moore P (2002) Communities in flames living with fire: summary of communities in flames international conference. In: Proceedings of an International Conference on Community Involvement in Fire Management. FAO, UN Regional Office for Asia and the Pacific, Bangkok, pp 1-9

Garren KH (1943) Effects of fire on vegetation on the Southern United States. Botanical Review journal 9(9):617-654

Goldammer JG (1993) Fire Management. Tropical forestry handbook 2(p):122

Huntley BJ (1982) Southern African savannas. In: Huntley BJ, Walker BH (eds) Ecology of tropical savannas. Springer-Verlag, Berlin, pp 101-109

Jackson WJ, Fisher JR (2007) Fire Management to Conserve Biodiversity and Protect Communities: A Global Perspective From a Conservation Conference, July 2007, Balikpapan, Indonesia

Jordan CF (1985) Nutrient cycling in tropical forest. John Wiley and Sons, Chichester, pp 190

Kilahama F (2011) Integrated Fire Management and Reduced Emissions through Deforestation and Degradation programme (REDDPLUS): In: Proceedings of the 5th International Wildland Fire Conference, Suncity, South Africa, p 19

Komarek EV (1972) Lightning The Fire Ecology. In Africa Proceedings of the Tall Timbers Fire Ecology Conference, Sindangbarang, Indonesia, pp 47-57

Laris P, Wardell DA (2006) Good, bad or 'necessary evil'? Reinterpreting the colonial burning experiments in the savanna landscapes of West Africa. Geographical Journal 172:271-290

Leaf C (2002) White-Collar Criminals. Fortune Magazine, New York

Mabeza MC, Mawere M (2012) Dambo cultivation in Zimbabwe: Challenges faced by small-scale dambo farming communities in Seke-Chitungwiza communal area. Journal of Sustainable Development in Africa 14(5):39-53

Machilis GE (2002) Burning questions: A social science research plan for federal wildland fire management. University of Idaho, Moscow

Magole L (2009) The 'shrinking commons' in the Lake Ngami grasslands, Botswana: the impact of national rangeland policy. Development Southern Africa 26:611-626

Moore P, Ganz D, Cheng Tan L, Enters T, Durst PB (eds) (2002) Communities in flames. Proceedings of an International Conference on Community Involvement in Fire Management. FAO. UN Regional Office for Asia and the Pacific Bangkok, Thailand, p 133

Mudekwe J (2007) Management Practices for the Protection of Forest Reserves the Case of Kalahari Sand Teak Forest Reserves in Western Zimbabwe. FAO, Rome, Available from: [http://www.fao.org/docrep/010/j9533e/j9533e00. htm]. Accessed 7 November 2012

Myers RL (2006) Living with fire-sustaining ecosystems and livelihoods through integrated fire management. Nature Conservancy, Tallahassee, FL, U.S.A., pp 28. http://www.biodiversity.ru/programs/steppe/pub/Myers_2006.pdf.

Nepstad DC, Moreira AG, Alencar AA (1999) Flames in the rain forest: Origins, impacts and alternatives to Amazonian fires. Pilot Program to Conserve the Brazilian Rain Forest, Brasilia

Nkomo GV, Sassi M (2009) Impact of wildland fires on land on smallholder farmers in Cashel Valley in Zimbabwe, Natural Resources and Agricultural Development and Food Security, International Research Network, International working paper series No. 09/02. Harare. pp 1-17

Nyamadzawo G, Gwenzi W, Kanda A, Kundhlande A, Masona C (2013) Understanding the causes, social and environmental impacts, and management of wildland fires in tropical Zimbabwe. Fire Science Reviews 2:9-13

Ortolano L (1997) Environmental Regulation and Impact Assessment. John Wiley \& Sons, New York

Philips R (1930) Effects of fire on forage level and performance of cattle. J Anim Sci 70:3889-3898

Phiri M, Zingwena S, Mahamba SM (2011) Community-based fire management; experiences from the FAO funded project in the provinces of Manicaland 
and Matebeleland North, Zimbabwe. In: FAO, Integrated fire approach: From global monitoring to natural fire management, Fire management working paper FM/27/E. FAO, Rome, pp 51-60. doi:10.1071/WF03015

Pinto C, Alvarado E (2011) Lessons learned on fire management in indigenous communities of Bolivia. In: Proceedings of the 5th International Wildland Fire Conference, Suncity, South Africa, pp 19

Sabiiti EN, Wein WR (1987) Fire and Acacia seeds: a hypothesis of colonisation success. J Ecol 75:937-946

Saharjo BH (1995) The changes in soil chemical properties following burning in a shifting cultivation area in South Sumatra, Indonesia. Wallaceana 75:23-26

Saharjo BH (2009) Why East Kalimantan Burns ? Wildfire magazine 7(7):19-21

Sampling Methods and Sample Size, calculation for the SMART Methodology June 2012. Available at: [https:/www.humanitarianresponse.info/system/files/ documents/files/Sampling_Paper_June_2012.pdf] Accessed 13/01/14

Shackleton CM, Scholes RJ (2000) Impact of fire frequency on woody community in the Kruger National Park. Koedoe 43(1):75-81

Sturgeon N (1997) Ecofeminist natures: race, gender, feminist theory, and political action. Routledge, New York

The Bible (2013) The British and Foreign Bible Society, Stonehill Green, westlea, Swindon, Wiltshire, United Kingdom., Available at, [http://www.biblesociety.org.uk/]

The Guardian 2015. http://www.theguardian.com/australia-news/2015/dec/26/ great-ocean-road-bushfire-destroys-more-than-50-homes. Accessed January 152016

The Herald (2011) Veld fires destroy 5 000ha. The Herald, Harare, [http://www. herald.co.zw/index.php?option=com_content\&view=article\&id=15631: veldfiresdestroy-5-000ha\&catid=47:agriculture\&ltemid=139]. Accessed 1 October 2012

Trollope WSW (1982) The Ecological Effects of Fire in South African Savannas. Ecology of Tropical Studies 42:292-308

Trollope WSW (1984) Fire in savanna. In: de Booysen PV, Tainton NM (eds) Ecological Effects of Fire in South African Ecosystems. Springer-Verlag, Berlin, pp 149-179

Van Lierop P (2011) Four years since Sevilla! Progress and challenges of integrated and community-based fire management, Integrated fire approach: From global monitoring to natural fire management, Fire management working paper FM/27/E. FAO, Rome, pp 43-49

Wegner T (2007) Applied business statistics: methods and Excel-based applications: solutions manual, 2nd edn, Juta Academic, Cape Town

West O (1972) Fire, Man and Wildlife as Interacting Factors Limiting the Development of Climax Vegetation in Rhodesia; Proceedings of the Tall Timbers Fire Ecology Conference Sindangbarang, Indonesia

Williams J, Albright D, Hoffmann AA, Eritsov A, Moore PF, Mendes De Morais JC, et al. (2011) Findings and Implications from a Coarse-Scale Global Assessment of Recent Selected Mega-Fires. FAO at the $5^{\text {th }}$ International Wildland Fire Conference Sun City, South Africa (9-13 May 2011), Available at: [http://www.fao.org/docrep/014/am663e/am663e00.pdf], Accessed; 2 August 2015

Wilson OE (1975) The New Synthesis, Twenty-Fifth Anniversary Edition. Harvard University Press, Lexington

World Wide Fund (WWF) (2001) Fire management manual. Wildlife management series. Harare

Zimstats Quarterly Digest, 2 ${ }^{\text {nd }}$ Quarter (2015) Available at: [http://www.zimstat.co. zw/sites/default/files/img/publications/Digest/Digest2015/Digest_2_2015.pdf] Accessed: 2 August 2015

Zumbrunnena T, Gianni B, Menéndezd P, Bugmannb H, Bürgia M, Conederac M (2011) Weather and human impacts on forest fires: 100 years of fire history in two climatic regions of Switzerland Forest Ecol Manag. 261:2188-2199.

\section{Submit your manuscript to a SpringerOpen ${ }^{\mathcal{O}}$ journal and benefit from:}

- Convenient online submission

- Rigorous peer review

- Immediate publication on acceptance

- Open access: articles freely available online

- High visibility within the field

- Retaining the copyright to your article 